\title{
SIMULASI POLA MEDAN ELEKTROMAGNET PADA PANDU GELOMBANG PERSEGI DENGAN DUA PARAMETER
}

\author{
Sujito $^{1)}$, Richard R Lokollo ${ }^{2)}$, Supadi $^{3)}$, Samian $^{4)}$, Era Budi P) $^{5}$ \\ ${ }^{1,5)}$ Jurusan Fisika, FMIPA, Universitas Negeri Malang \\ ${ }^{2)}$ Jurusan Fisika, FMIPA, Universitas Pattimura Ambon \\ ${ }^{3,4)}$ Departemen Fisika, Fakultas Sains dan Teknologi, Unair Surabaya \\ soejito.fmipa@um.ac.id
}

\begin{abstract}
ABSTRAK
Telah dilakukan visualisasi pola medan elektromagnetik pada pandu gelombang persegi untuk moda berorde tinggi, yaitu moda $\mathrm{TE}_{00}, \mathrm{TE}_{01}, \mathrm{TE}_{10}$ dan $\mathrm{TE}_{11}$. Konstanta propagasi sebagai salah satu parameter yang digunakan untuk mengkarakter moda gelombang optik diformulasikan secara semi analitik. Hal ini dikarenakan formulasi konstanta propagasi efektif moda gelombang tidak dapat diturunkan secara eksak. Beberapa bagian dipecahkan menggunakan penyelesaian analitik, sedangkan beberapa bagian diselesaikan melalui analisa numerik secara komputasional dengan menggunakan perangkat lunak Matlab. Analisis karakter pola medan dilakukan dengan menggunakan prinsip Variasional fungsi trial polinom Hypergeometri. Hasil penelitian menunjukkan bahwa profil indeks bias berbentuk secant hyperbolik. Hal ini menunjukkan bahwa penggunaan berbagai orde moda menunjukkan kesesuaian terhadap metode indeks efektif dan mampu mendeskripsikan pola medan.
\end{abstract}

Kata Kunci : Persegi; pola medan; moda;

\begin{abstract}
ABSTRACK
Visualization of the electromagnetics field has been done to rectangular optic waveguide for high order moda. That is moda of $\mathrm{TE}_{00}, \mathrm{TE}_{01}, \mathrm{TE}_{10}$ dan $\mathrm{TE}_{11}$. The purpose of this research is description model of electromagnetic wave propagation TE modus to rectangular wave guide. Propagation constant are parameter for characteristic optical wave moda. It's use semy analytic formulation. The constant propagation can not define according exact solution. Solution for some parts using analytical formulation. Some parts of equation solve using numerical analysis with Matlab software. The characteristics of field pattern must analyze with Hypergeometry polynom trial. Result of this research is refraction index profile organized as secant hyperbolic. It's mean that orde mode whom using this result concord to method of effective index, so field of electromagnetic can be well describe.
\end{abstract}

Key words: rectangular; field pattern; mode;

\section{PENDAHULUAN}

Aplikasi piranti optik mempunyai peran yang besar pada masa perkembangan ilmu pengetahuan dan teknologi, khususnya aplikasi untuk sensor fotonik, piranti komunikasi dan switching fotonik. Komponen dasar optika terpadu yang digunakan adalah pandu gelombang. Salah satu dasar optika terpadu yang sering dipakai adalah struktur lapis jamak dan terbuat dari bahan tak linier (1). Piranti optik jenis ini memiliki banyak aplikasi dalam 
bidang optoelektronik, misalnya pembangkit laser harmonik kedua, atau sebagai bistabilitas.

Salah satu struktur pandu gelombang optik adalah struktur persegi (rectangular) (2). Pandu gelombang optik persegi (rectangular) mempunyai dinding konduktor logam dengan konduktivitas $\sigma_{c}$ yang tinggi (3). Ruang yang berada dalam pandu gelombang merupakan medium dielektrik sempurna (seperti udara) dengan permeabilitas magnetik $\mu$ dan permitivitas listrik $\varepsilon$. Tampilan fisik berupa lebar pandu pada sumbu kartesian arah $\mathrm{x}$ adalah a, dan y adalah b. Panjangnya tak berhingga dalam arah z. Gelombang menjalar di dalam rongga arah sumbu $\mathrm{z}$ seperti aliran cairan dalam pipa $(1,4)$. Untuk lebih jelas, perhatikan Gambar 1. Pada pandu gelombang persegi, pengurungan berkas gelombang terpandu terjadi dikedua arah sumbu transversal (memperkecil efek difraksi) sepanjang arah perambatan $(3,5)$. Kuantitas fisis yang dikenal sebagai moda perambatan gelombang merupakan salah satu karakteristik rambatan.

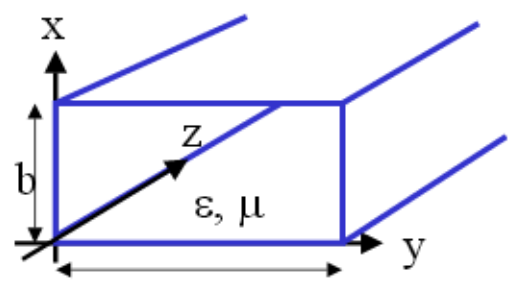

a

Gambar 1. Geometri Pandu Gelombang Persegi

Tujuan studi dalam penelitian ini adalah memberikan pemodelan gelombang elektromagnetik modus TE pada pandu gelombang persegi. Pola medan listrik diasumsikan mematuhi fungsi kuadrat hyperbolik $\left(\operatorname{sech}^{2}\right)$ dengan orde moda ke-n $(n=0,1,2 \ldots)(8)$. Penyelesaian terhadap fungsi tersebut dilakukan secara analitik menggunakan persamaan Helmholtz (4,5,7). Distribusi ini mampu digunakan sebagai dugaan awal untuk model numerik. Selain itu, analisis pola medan memerlukan titik-titik data untuk membuat simulasi $(3,7)$.

Medan cobaan hasil pemodelan digunakan untuk menghitung parameter $\beta$ yang formulasinya diturunkan dari analisis variasional. Secara keseluruhan, baik perhitungan, penjabaran maupun analisa diasumsikan bahwa persamaan gelombang skalar dipenuhi dalam kondisi stasioner. Salah satu metode yang digunakan adalah skalar variasional dengan pendekatan Hypergeometri-secant Hyperbolik (9). Analisis variasional skalar disajikan untuk mempelajari karakteristik propagasi lemah dengan bentuk gaussian dan merapikan out put dari profil indeks bias.

\section{Pendekatan Hypergeometri-secant Hyperbolik}

Prinsip yang digunakan dalam model ini adalah kalkulus variasional $(3,9)$. Artinya, bila fungsi adalah stasioner, maka persamaan Euler untuk fungsi tersebut terpenuhi. Persamaan umum gelombang skalar adalah

$$
\nabla^{2} \psi+\mathrm{k}_{0}^{2} \mathrm{n}^{2} \psi
$$

Solusi skalar Maxwell akan dipenuhi oleh persamaan Euler untuk fungsi 


$$
\mathrm{I}=\iiint_{\mathrm{v}}\left[\left(\nabla \psi \cdot \nabla \psi^{*}\right)-\mathrm{n}^{2} \mathrm{k}_{0}^{2} \psi \psi^{*}\right] \mathrm{dv}
$$

sehingga medan skalar yang dipenuhi memberikan nilai stasioner untuk I $(I=0)$, maka solusi persamaan 1 berbentuk

$$
\psi(\mathrm{x}, \mathrm{y}, \mathrm{z})=\psi(\mathrm{x}, \mathrm{y}) \mathrm{e}^{-\mathrm{j} \beta \mathrm{z}}
$$

Ekspresi variasional untuk $\beta^{2}$ dapat dinyatakan menurut relasi 1, 2, 3

$$
\beta^{2}=\frac{\iint_{-\sim}^{+\sim}\left[\mathrm{k}_{0}^{2}{ }^{2}(\mathrm{x}, \mathrm{y}) \psi \psi^{*}-\left(\nabla_{\mathrm{t}} \psi\right) \cdot\left(\nabla_{\mathrm{t}} \psi^{*}\right)\right] \mathrm{dxdy}}{\iint_{-\sim}^{+} \psi \psi^{*} \mathrm{dxdy}}
$$

Persamaan Euler yang dipenuhi oleh $\beta^{2}$ merupakan persamaan gelombang skalar. Karena gelombang skalar memenuhi kondisi persamaan Euler, maka bentuk $\beta^{2}$ adalah stasioner. Untuk variasi kecil dari $\psi(\mathrm{x}, \mathrm{y})$ disekitar solusi tersebut, $\beta^{2}$ akan bernilai stasioner $(2,3,5,9)$.

\section{Distribusi Medan Polinom Fungsi Trial}

Untuk menganalisis perhitungan parameter $\beta$ menggunakan metode analisa skalar variasional, digunakan medan fungsi cobaan (fungsi trial) yang sesuai sebagai fungsi pendekatan moda gelombang optik. Pada makalah ini diperlihatkan pemodelan medan fungsi cobaan Hypergeometri-Secant hyperbolik satu dimensi (1-D). Bentuk dua dimensi (2-D) diperoleh secara langsung dengan mengalikan kedua fungsi 1-D (3,7,8). Pemodelan medan fungsi cobaan Hypergeometri-Secant hyperbolik 1-D modus TE, dilakukan dengan mensubtitusikan fungsi profil distribusi indeks bias $1 / \cosh ^{2}$ yang berbentuk

$$
\mathrm{n}^{2}(\mathrm{x})=\mathrm{n}_{\mathrm{S}}^{2}+2 \mathrm{n}_{\mathrm{s}} \Delta \mathrm{n} / \cosh ^{2}(2 \mathrm{x} / \mathrm{h})
$$

ke persamaan Helmholtz hasil pemecahan Persamaan 3 yang disubtitusikan ke persamaan (1) yaitu

$$
\nabla_{\mathrm{t}}^{2} \psi(\mathrm{x})+\left(\mathrm{k}_{0}^{2} \mathrm{n}^{2}(\mathrm{x})-\beta^{2}\right) \psi(\mathrm{x})=0
$$

Hasilnya diperoleh medan cobaan berbentuk distribusi polinomial (1):

$$
\psi_{\mathrm{n}}(\mathrm{x})=\mathrm{U}_{\mathrm{n}}(2 \mathrm{x} / \mathrm{h}) / \cos ^{\mathrm{s}}(2 \mathrm{x} / \mathrm{h})
$$

Persamaan 7 merupakan pola medan skalar cobaan polinomial Hypergeometri-Secant Hyperbolik untuk setiap orde moda ke-n, dengan $\mathrm{U}_{\mathrm{n}}$ adalah fungsi Hypergeometri. 3 orde pertama pada persamaan 7, masing-masing pola medan skalar orde ke-n dinormalisasikan menggunakan hubungan relasi dispersi (9). Dengan memanfaatkan fungsi identitas pada fungsi beta dan gamma, maka diperoleh 3 moda orde pertama untuk medan fungsi cobaan ternormalisasi dalam bentuk distribusi polinom Hypergeometri-Secan hyperbolik yaitu :

$$
\begin{aligned}
& \psi_{0}=\sqrt{\frac{2}{\mathrm{~h}}}\left(\frac{1}{\pi}\right)^{\frac{1}{4}} \sqrt{\frac{\Gamma(\mathrm{s}+1 / 2)}{\Gamma(\mathrm{s})}} \operatorname{sech}^{\mathrm{s}}\left(\frac{2 \mathrm{x}}{\mathrm{h}}\right) \\
& \psi_{1}=\sqrt{\frac{2}{\mathrm{~h}}}\left(\frac{1}{\pi}\right)^{\frac{1}{4}}\left[\frac{\Gamma(s-1)}{\Gamma(s-1 / 2)}-\frac{\Gamma(s)}{\Gamma(s+1 / 2)}\right]^{-\frac{1}{2}} \mathrm{x} \sinh \left(\frac{2 \mathrm{x}}{\mathrm{h}}\right) \operatorname{sech}^{\mathrm{s}}\left(\frac{2 \mathrm{x}}{\mathrm{h}}\right) \\
& \psi_{2}=\sqrt{\frac{2}{\mathrm{~h}}}\left(\frac{1}{\pi}\right)^{\frac{1}{4}}\left[1-2(\mathrm{~s}-1) \sinh ^{2}(2 \mathrm{x} / \mathrm{h})\right] \operatorname{sech}^{\mathrm{s}}(2 \mathrm{x} / \mathrm{h}) \times\left[\frac{\Gamma(\mathrm{s})}{\Gamma(\mathrm{s}+1 / 2)}-4(s-1)\left(\frac{\Gamma(s-1)}{\Gamma(s-1 / 2)}-\frac{\Gamma(s)}{\Gamma(s+1 / 2)}\right)\right.
\end{aligned}
$$




$$
\left.+4(s-1)^{2}\left(\frac{\Gamma(s-2)}{\Gamma(s-3 / 2)}-2 \frac{\Gamma(s-1)}{\Gamma(s-1 / 2)}+\frac{\Gamma(s)}{\Gamma(s+1 / 2)}\right)\right]-\frac{1}{2}
$$

\section{Moda dasar Pandu Gelombang Persegi}

Fungsi distribusi Hypergeometri 2 dimensi untuk moda dasar dengan 1 parameter lebar seperti diperlihatkan pada persamaan 8,9 dan 10, dimodifikasi untuk dua parameter lebar, maka diperoleh medan fungsi cobaan moda dasar 2-D yaitu (9)

$$
\psi_{00}(\mathrm{x}, \mathrm{y})=\frac{2}{\sqrt{\mathrm{h}_{\mathrm{x}} \mathrm{h}_{\mathrm{y}} \pi}} \sqrt{\frac{\Gamma\left(\mathrm{s}_{\mathrm{x}}+1 / 2\right)}{\Gamma\left(\mathrm{s}_{\mathrm{x}}\right)}} \sqrt{\frac{\Gamma\left(\mathrm{s}_{\mathrm{y}}+1 / 2\right)}{\Gamma\left(\mathrm{s}_{\mathrm{y}}\right)}} \operatorname{sech}^{\mathrm{s}_{\mathrm{x}}}\left(\frac{2 \mathrm{x}}{\mathrm{h}_{\mathrm{x}}}\right) \mathrm{x} \operatorname{sech}^{\mathrm{s} \mathrm{y}}\left(\frac{2 \mathrm{y}}{\mathrm{h}_{\mathrm{y}}}\right)
$$

Hasil ini kemudian di masukkan ke persamaan 4, diperoleh

$$
\beta^{2}=\frac{4 \mathrm{k}_{0}^{2}}{\mathrm{~h}_{\mathrm{x}} \mathrm{h}_{\mathrm{y}} \pi}\left(\frac{\Gamma\left(\mathrm{s}_{\mathrm{x}}+1 / 2\right) \Gamma\left(\mathrm{s}_{\mathrm{y}}+1 / 2\right)}{\Gamma\left(\mathrm{s}_{\mathrm{x}}\right) \Gamma\left(\mathrm{s}_{\mathrm{y}}\right)}\right) \iint_{-\sim}^{+} \mathrm{n}^{2}(\mathrm{x}, \mathrm{y}) \operatorname{sech}^{2 \mathrm{~s}_{\mathrm{x}}}\left(\frac{2 \mathrm{x}}{\mathrm{h}_{\mathrm{x}}}\right) \mathrm{x} \operatorname{sech}^{2 \mathrm{~s} y}\left(\frac{2 \mathrm{y}}{\mathrm{h}_{\mathrm{y}}}\right) \mathrm{dxdy}-\frac{2 \mathrm{~s}_{\mathrm{x}}^{2}}{\mathrm{~h}_{\mathrm{x}}^{2}}\left(\frac{\Gamma\left(\mathrm{s}_{\mathrm{x}}+1 / 2\right)}{\Gamma\left(\mathrm{s}_{\mathrm{x}}+3 / 2\right.}\right) . .
$$

Syarat $\beta^{2}$ mencapai stasioner adalah $\frac{\partial \beta^{2}}{\partial \mathrm{h}_{\mathrm{x}}}=0$ dan $\frac{\partial \beta^{2}}{\partial \mathrm{h}_{\mathrm{y}}}=0$. Untuk mempermudah pemecahan persamaan 12 dilakukan metode secara numerik. Dengan mengasumsikan struktur pandu gelombang sebagaimana dalam Gambar 2 (indeks bias konstan dan relasi dari persamaan 5 untuk $\left.\mathrm{n}^{2}(\mathrm{x}, \mathrm{y})\right)$, diperoleh solusi untuk $\beta^{2}$ berupa:

$$
\begin{aligned}
& \beta^{2}=k_{0}^{2}\left\{D^{\prime}+\left(-A^{\prime}\right)_{-d_{x} / 2}^{d_{x} / 2} \operatorname{sech}^{2 s_{x}}\left(\frac{2 x}{h_{x}}\right) d x+\left(-B^{\prime}\right)_{-d_{y} / 2}^{d_{y} / 2} \operatorname{sech}^{2} 2 s_{y}\left(\frac{2 y}{h_{y}}\right) d y\right. \\
& \left.+\left(-C^{\prime}\right)_{-d_{x} / 2}^{d_{x} / 2} \operatorname{sech}^{2 s_{x}}\left(\frac{2 x}{h_{x}}\right) d x \underset{-d_{y} / 2}{d_{y} / 2} \operatorname{sech}^{2 s_{y}}\left(\frac{2 y}{h_{y}}\right) d y\right\}-\frac{2 s_{x}^{2}}{h_{x}^{2}}\left(\frac{\Gamma\left(s_{x}+1 / 2\right)}{\Gamma\left(s_{x}+3 / 2\right.}\right)-\frac{2 s_{y}^{2}}{h_{y}^{2}}\left(\frac{\Gamma\left(s_{y}+1 / 2\right)}{\Gamma\left(s_{y}+3 / 2\right.}\right) \ldots \ldots .
\end{aligned}
$$

Persamaan 1 menunjukkan bahwa jika $\mathrm{h}_{\mathrm{x}}=\mathrm{h}_{\mathrm{y}}=\mathrm{h}$, maka akan dihasilkan persamaan umum yang berlaku untuk satu parameter lebar. Konsistensi dalam memberikan masukan pada pendekatan ini tetap terjaga. Untuk memberikan gambaran struktur yang jelas maka perhatikan Gambar $2(1,3,6)$.

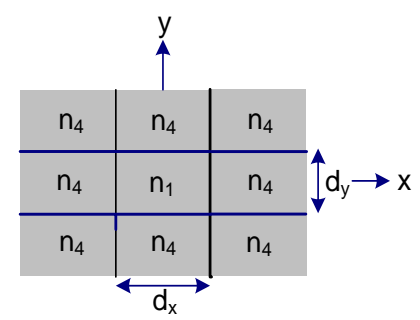

Gambar 2. Bentuk spesifik pandu gelombang persegi (tipe buried)

Geometri spesifik daerah pandu gelombang persegi indeks $n_{1}$ dikelilingi oleh daerah berindeks $\mathrm{n}_{4}$ (Gambar 2). Parameter $\beta^{2}$ pada persamaan 12 selanjutnya dipecahkan menggunakan relasi dispersi. Pendefinisian lebar ternormalisasi 2 parameter lebar dinyatakan $(3,4)$

$$
\mathrm{Nh}_{\mathrm{x}}=\frac{\mathrm{h}_{\mathrm{x}}}{\mathrm{d}_{\mathrm{x}}}, \mathrm{Nh}_{\mathrm{y}}=\frac{\mathrm{h}_{\mathrm{y}}}{\mathrm{d}_{\mathrm{y}}} \text { dan aspek rasio } \mathrm{a}=\frac{\mathrm{d}_{\mathrm{x}}}{\mathrm{d}_{\mathrm{y}}}
$$

Solusi medan B adalah 


$$
\begin{aligned}
& \mathrm{B}=\frac{4}{\left(\mathrm{Nh}_{\mathrm{x}} \mathrm{V}\right)\left(\mathrm{Nh}_{\mathrm{y}} \mathrm{V}\right) \pi}\left(\frac{\Gamma\left(\mathrm{s}_{\mathrm{x}}+1 / 2\right)}{\Gamma\left(\mathrm{s}_{\mathrm{x}}\right)}\right) \times\left(\frac{\Gamma\left(\mathrm{s}_{\mathrm{y}}+1 / 2\right)}{\Gamma\left(\mathrm{s}_{\mathrm{y}}\right)}\right) \int_{\mathrm{V} / 2}^{\mathrm{V} / 2} \operatorname{sech}^{2 \mathrm{~s}_{\mathrm{x}}}\left(\frac{2 \xi}{\mathrm{Nh}_{\mathrm{x}} \mathrm{V}}\right) \mathrm{d} \xi \\
& \left.\mathrm{x} \int_{-\mathrm{V} / 2}^{\mathrm{V} / 2} \operatorname{sech}^{2 \mathrm{~s}_{\mathrm{y}}}\left(\frac{2 \xi^{\prime}}{\mathrm{Nh}_{\mathrm{y}} \mathrm{V}}\right) \mathrm{d} \xi^{\prime}-\frac{2 \mathrm{~s}_{\mathrm{x}}^{2}}{\mathrm{a}^{2} \mathrm{~V}^{2}\left(\mathrm{Nh}_{\mathrm{x}}\right)^{2}}\left(\frac{\Gamma\left(\mathrm{s}_{\mathrm{x}}+1 / 2\right)}{\Gamma\left(\mathrm{s}_{\mathrm{x}}+3 / 2\right.}\right)-\frac{2 \mathrm{~s}_{\mathrm{y}}^{2}}{\mathrm{~V}^{2}\left(\mathrm{Nh}_{\mathrm{y}}\right)^{2}}\left(\frac{\Gamma\left(\mathrm{s}_{\mathrm{y}}+1 / 2\right)}{\Gamma\left(\mathrm{s}_{\mathrm{y}}+3 / 2\right)}\right)\right] .
\end{aligned}
$$

\section{Moda orde tinggi}

Deskripsi kondisi medan pada moda pandu gelombang berorde tinggi berstruktur persegi dapat ditentukan menggunakan langkah yang sama dengan di moda dasar $(3,5,8,9)$.

Ambil kasus pada moda $(0,1)$, bentuk distribusi polinom Hypergeometri-Secant Hyperbolik model 1-D dalam arah kedua sumbu transversal dinyatakan dalam fungsi medan cobaan sebagaimana dalam persamaan berikut.

$$
\begin{aligned}
& \psi_{0}(\mathrm{x})=\sqrt{\frac{2}{\mathrm{~h}_{\mathrm{x}}}}\left(\frac{1}{\pi}\right)^{\frac{1}{4}} \sqrt{\frac{\Gamma\left(\mathrm{s}_{\mathrm{x}}+1 / 2\right)}{\Gamma\left(\mathrm{s}_{\mathrm{x}}\right)}} \operatorname{sech}^{\mathrm{s}_{\mathrm{x}}}\left(\frac{2 \mathrm{x}}{\mathrm{h}_{\mathrm{x}}}\right) \\
& \psi_{1}(\mathrm{y})=\frac{2}{\sqrt{\mathrm{h}_{\mathrm{y}}}}\left(\frac{1}{4}\right)^{\frac{1}{4}} \sqrt{\frac{\Gamma\left(\mathrm{s}_{\mathrm{y}}+1 / 2\right)}{\Gamma\left(\mathrm{s}_{\mathrm{y}}-1\right)}} \sinh \left(\frac{2 \mathrm{y}}{\mathrm{h}_{\mathrm{y}}}\right) \operatorname{sech}^{\mathrm{s}_{\mathrm{y}}\left(\frac{2 \mathrm{y}}{\mathrm{h}_{\mathrm{y}}}\right)}
\end{aligned}
$$

Medan fungsi trial sebagaimana dalam persamaan 15 (arah x (orde nol) dan y (orde satu)) dihasilkan medan fungsi cobaan moda $(0,1)$ 2-D dengan dua parameter lebar, yaitu $(1,3,6,9)$

$$
\psi_{01}(\mathrm{x}, \mathrm{y})=\frac{2}{\sqrt{\mathrm{h}_{\mathrm{x}} \mathrm{h}_{\mathrm{y}}}}\left(\frac{2}{\pi}\right)^{\frac{1}{2}} \sqrt{\frac{\Gamma\left(\mathrm{s}_{\mathrm{x}}+1 / 2\right)}{\Gamma\left(\mathrm{s}_{\mathrm{x}}\right)}} \sqrt{\frac{\Gamma\left(\mathrm{s}_{\mathrm{y}}+1 / 2\right)}{\Gamma\left(\mathrm{s}_{\mathrm{y}}-1\right)}} \operatorname{sech}^{\mathrm{s}_{\mathrm{x}}}\left(\frac{2 \mathrm{x}}{\mathrm{h}_{\mathrm{x}}}\right) \mathrm{x} \sinh \left(\frac{2 \mathrm{y}}{\mathrm{h}_{\mathrm{y}}}\right) \operatorname{sech}^{\mathrm{s}_{\mathrm{y}}}\left(\frac{2 \mathrm{y}}{\mathrm{h}_{\mathrm{y}}}\right) \cdots
$$

Persamaan eigen fungsi cobaan $\psi_{01}(\mathrm{x}, \mathrm{y})$ dalam 16 disubstitusikan ke persamaan 4 untuk mendapatkan persamaan $\beta^{2}$. Dengan menerapkan syarat stasioner dari $\beta^{2}$ yang memenuhi $\frac{\partial \beta^{2}}{\partial \mathrm{h}_{\mathrm{x}}}=0$ dan $\frac{\partial \beta^{2}}{\partial \mathrm{h}_{\mathrm{y}}}=0$, maka nilai optimal parameter variasi $\mathrm{h}_{\mathrm{x}}$ dan $\mathrm{h}_{\mathrm{y}}$ dapat ditentukan.

\section{METODE PENELITIAN}

Langkah yang harus dilakukan untuk menentukan karakter moda rambatan pandu gelombang rektangular adalah menghitung konstanta propagasi $\beta(2,5,6)$. Metode yang digunakan adalah metode analisa skalar variasional. Skema analitik pada metode ini memberikan improvisasi akurasi data yang mampu menghasilkan point-point medan untuk membentuk distribusi grid data tidak teratur sebagai hasil simulasi dalam domain ruang $(5,8)$. Pendekatan ini dilakukan karena $\beta$ pada pandu gelombang rectangular tidak tersedia secara analitis.

Pemodelan dimulai dengan membuat pemodelan persamaan matematis. Gejala fisis diuraikan dalam bentuk parameter secara simbolis dan matematis dalam bentuk persamaan tertentu. Distribusi medan tidak akan simetri jika medan tidak simetri dalam distribusi indeks bias. Ketidaksimetrian ini dapat terjadi karena lebar kanal yang berbeda $\left(\mathrm{d}_{\mathrm{x}} \neq \mathrm{d}_{\mathrm{y}}\right)$ atau perbedaan nilai indeks pada daerah-daerah di luar kanal (yaitu $: n_{i} \neq n_{j}, i, j \neq 1$ ) (3). Untuk mendapatkan ketidaksimetrian dalam perhitungan, diaplikasikan suatu variasi terhadap pendekatan fungsi polinom Hypergeometri-Secant Hyperbolik. Dalam hal ini, 
persamaan fungsi medan cobaan Hypergeometri-Secant Hyperbolik dalam arah x dan y memuat dua parameter lebar yang berbeda. Moda digunakan karena dalam proses pemanduan cahaya memiliki kaitan yang erat dengan fenomena sinar optik pada bidang batas antara dua medium.

Untuk menyederhanakan permasalahan, maka perhitungan dan analisa dilakukan secara semi analitik dimana sebagian persamaan dipecahkan secara analitik dan komputasional. Program yang digunakan adalah Matlab 6.5. Input secara numerik dilakukan dengan mengasumsikan beberapa parameter utama baik $\beta$ maupun parameter variasi lebar pandu (bukan lebar yang sebenarnya) dinyatakan dalam parameter ternormalisasi.

Perhitungan komputasi dilakukan dengan menyatakan $\beta^{2}, \mathrm{~h}, \mathrm{~h}_{\mathrm{x}}$ dan $\mathrm{h}_{\mathrm{y}}$ dalam $\mathrm{B}$ dan $\mathrm{Nh}, \mathrm{Nh}_{\mathrm{x}}$ dan $\mathrm{Nh}_{\mathrm{y}}$. Integral tentu dari parameter $\mathrm{B}$ pada lapisan pemandu struktur pandu gelombang dipecahkan dengan metode 'Simpson 1/3 banyak segmen' yang didasarkan pada pendekatan kuadratik (polinomial orde tinggi) dengan jumlah segmen diambil $\mathrm{n}=$ $100(3,4,6)$. Perhitungan $\frac{\partial \beta^{2}}{\partial \mathrm{h}}$ dinyatakan berbentuk $\frac{\partial \mathrm{B}}{\partial \mathrm{Nh}}$, dilakukan secara numerik menggunakan metode derivatif beda central (4 segmen untuk setiap sub interval, dengan lebar setiap segmen 0,01). Sedangkan penentuan nilai h atau dinyatakan dalam $\mathrm{Nh}$ yang memenuhi $\frac{\partial \mathrm{B}}{\partial \mathrm{Nh}}=0$ dilakukan menggunakan metode secant dengan toleransi $10^{-6}$ serta menggunakan dua tebakan awal $\mathrm{Nh}_{1}=0,9$ dan $\mathrm{Nh}_{2}=0,91$. Nilai $\mathrm{Nh}, \mathrm{Nh}_{\mathrm{x}}$ dan $\mathrm{Nh}_{\mathrm{y}}$ optimal yang telah diperoleh dimasukkan kembali untuk mendapatkan nilai $\mathrm{B}$.

Secara garis besar untuk mengaplikasikan metode skalar variasional dalam menentukan $\beta^{2}$ dan nilai parameter variasi $\mathrm{P}_{\mathrm{i}}$, maka beberapa tahapan yang perlu dilakukan yaitu (9):

1. Melakukan pendekatan parametrik untuk medan fungsi cobaan $\Psi(\mathrm{x}, \mathrm{y})$ untuk moda orde ke-n.

2. Mensubtitusi pendekatan ke persamaan (4) untuk mendapatkan persamaan untuk $\beta^{2}$

3. Untuk memperoleh nilai parameter variasi $\mathrm{P}_{\mathrm{i}}$, maka $\beta^{2}$ dinyatakan bernilai stasioner, sehingga nilai parameter variasi $\mathrm{P}_{\mathrm{i}}$ ditentukan melalui syarat stasioner $\frac{\partial \beta^{2}}{\partial \mathrm{P}_{\mathrm{i}}}=0$

4. Solusi parameter variasional dari langkah (3) disubtitusikan kedalam persamaan pada langkah (2) untuk mendapatkan nilai dari $\beta^{2}$.

\section{HASIL DAN PEMBAHASAN}

\section{Moda Dasar}

Hasil perhitungan dan analisa karakteristik perambatan moda gelombang optik moda dasar pandu gelombang persegi 2 parameter lebar h untuk a $=2$ disajikan dalam Tabel 1 . Hasil ini didapat dengan memvariasi lebar pandu gelombang h yang dibatasi pada kedua sumbu transversal, yaitu $h_{x}$ dan $h_{y}$. 
Tabel 1. Nilai B, $\mathrm{Nh}_{\mathrm{x}}$ dan $\mathrm{Nh}_{\mathrm{y}}$ untuk moda orde 0

\begin{tabular}{ccccccc}
\hline $\mathrm{V}$ & $\mathbf{N h}_{\mathbf{x}}$ & $\mathbf{N h}_{\mathbf{y}}$ & $\mathbf{N W}_{\mathbf{x}}$ & $\mathbf{N W}_{\mathbf{y}}$ & $\mathbf{B}_{\text {hyper }}$ & $\mathbf{B}_{\text {hermite }}$ \\
\hline 1 & - & - & - & - & - & - \\
2 & 1.3428 & 0.9163 & 1.2055 & 1.9177 & 0.0984 & 0.1487 \\
3 & 1.4281 & 0.9892 & 1.0009 & 1.3429 & 0.3521 & 0.4695 \\
4 & 1.4534 & 1.0333 & 0.9126 & 1.1177 & 0.5308 & 0.6294 \\
5 & 1.4781 & 1.1223 & 0.8714 & 0.9954 & 0.6455 & 0.7162 \\
6 & 1.4981 & 1.2156 & 0.8372 & 0.913 & 0.7169 & 0.7722 \\
7 & 1.5332 & 1.3099 & 0.7681 & 0.8517 & 0.7622 & 0.8098 \\
8 & 1.5890 & 1.4014 & 0.7538 & 0.823 & 0.7922 & 0.8367 \\
9 & 1.6218 & 1.4916 & 0.7485 & 0.8147 & 0.8129 & 0.8561 \\
10 & 1.7602 & 1.5801 & 0.7267 & 0.7824 & 0.8282 & 0.8711 \\
11 & 1.9137 & 1.6667 & 0.7032 & 0.7586 & 0.8394 & 0.8828 \\
12 & 2.1059 & 1.7514 & 0.6922 & 0.7371 & 0.8483 & 0.8921 \\
13 & 2.0994 & 1.8344 & 0.6821 & 0.7185 & 0.8554 & 0.8997 \\
14 & 2.2465 & 1.9157 & 0.6686 & 0.7023 & 0.8614 & 0.9059 \\
15 & 2.4825 & 1.9956 & 0.6604 & 0.688 & 0.8664 & 0.9110 \\
16 & 2.7179 & 2.0741 & 0.6496 & 0.6752 & 0.8706 & 0.9154 \\
\hline
\end{tabular}

Tabel 1 dan kurva dispersi sebagaimana dalam Gambar 7 menunjukkan akurasi perhitungan nilai konstanta propagasi ternormalisasi (B) untuk kedua pendekatan yang semakin bertambah dengan meningkatnya harga frekuensi ternormalisasi (V). Jika analisa difokuskan pada $\mathrm{V}$ rendah. Penambahan parameter variasi lebar dengan $\mathrm{a}=2$ untuk pendekatan Hypergeometri menambah keakurasian terhadap perhitungan nilai B.

Grafik hubungan antara B dan v pada pandu gelombang persegi moda dasar untuk 2 parameter lebar dengan aspect Ratio a $=2$ disajikan dalam Gambar 3. Garis merah (-) merupakan metode pendekatan Hermite-Gaussian, sedangkan titik biru (.) merupakan metode pendekatan Hypergeometri-sech. Secara fisis penambahan parameter variasi akan memperkecil ralat relatif terhadap medan cobaan yang diambil. Hal ini berbalikan dengan pendekatan Hermite-Gaussian yang seharusnya V cut-off untuk 2 parameter lebar harus sedikit lebih kecil dari V cut-off pada 1 parameter lebar untuk aspect ratio yang sama $(\mathrm{a}=$ 2).

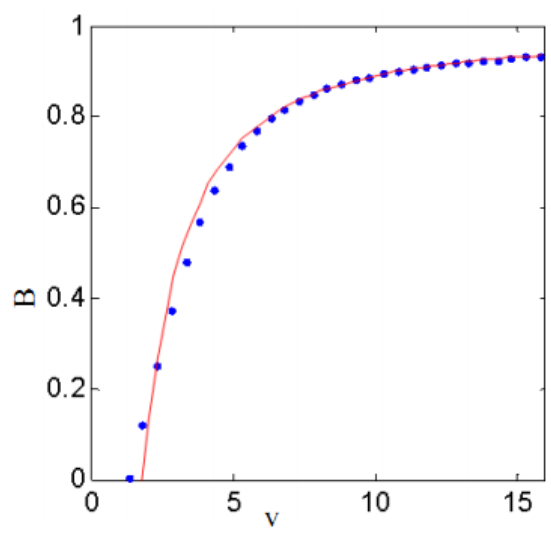

Gambar 3. Hubungan B (Konstanta propagasi ternormalisasi) vs v (Frekuensi ternormalisasi) 
Sebagaimana hasil komputasi dalam Gambar 3, pengaruh 2 parameter lebar untuk pendekatan Hypergeometri sangat kecil. Hal ini berarti walaupun menambah akurasi terhadap hasil perhitungan tetapi perubahannya tidak terlalu signifikan. Analisa yang digunakan dalam penelitian belum menunjukkan nilai yang signifikan, tetapi belum ada metode standart untuk menguji keakurasian kedua fungsi pendekatan $(3,8)$. Oleh karena itu, landasan yang digunakan adalah menguji keakurasian yang berpijak pada daerah cutoff pandu gelombang slab. Pada pandu gelombang slab, untuk $\mathrm{V}$ yang cenderung mendekati 0 dari kurva dispersi $\mathrm{B}$ vs $\mathrm{V}$, makin besar lebar jendela optisnya dan makin besar energi gelombang cahaya terkurung. Berdasarkan analisa ini, maka model 2 parameter variasi lebar pendekatan Hypergeometri dapat dinyatakan lebih akurat jika dibandingkan dengan pendekatan Hermite-Gaussian untuk frekuensi ternormalisasi rendah.

\section{Orde Tinggi}

Tabel 2 merupakan hasil perhitungan komputasi Nilai $\mathrm{B}, \mathrm{Nh}_{\mathrm{x}}$ dan $\mathrm{Nh}_{\mathrm{y}}$ untuk modamoda ber orde tinggi pandu gelombang persegi step indeks 2 parameter lebar dengan $\mathrm{a}=$ 1. Penghitungan dilakukan dengan pendekatan skalar variasional menggunakan fungsi cobaan Hypergeometri-Secant Hyperbolik.

\begin{tabular}{ccccccc}
\multicolumn{6}{c}{ Tabel 2. Nilai $\mathrm{B}, \mathrm{Nh}_{\mathrm{x}}$ dan $\mathrm{Nh}_{\mathrm{y}}$ untuk modus TE00 } \\
\hline $\mathbf{V}$ & $\mathbf{N h x}$ & $\mathbf{N h y}$ & $\mathbf{N W x}$ & $\mathbf{N W y}$ & $\mathbf{B}_{\text {hyper }}$ & $\mathbf{B}_{\text {hermite }}$ \\
\hline 1 & - & - & - & - & - & - \\
2 & 1.3209 & 1.3209 & - & - & 0.0381 & - \\
3 & 1.0885 & 1.0876 & 1.4359 & 1.4341 & 0.2854 & 0.1383 \\
4 & 1.0669 & 1.0674 & 1.2102 & 1.2073 & 0.4688 & 0.4399 \\
5 & 1.1449 & 1.1080 & 1.0818 & 1.0807 & 0.5940 & 0.5962 \\
6 & 1.2097 & 1.2126 & 1.0008 & 1.0016 & 0.6792 & 0.6889 \\
7 & 1.3024 & 1.3014 & 0.9387 & 0.9387 & 0.7386 & 0.7486 \\
8 & 1.3939 & 1.3957 & 0.9100 & 0.9100 & 0.7812 & 0.7898 \\
9 & 1.4842 & 1.4844 & 0.9017 & 0.9017 & 0.8126 & 0.8190 \\
10 & 1.5726 & 1.5726 & 1.8710 & 0.8366 & 0.8366 & 0.8411 \\
11 & 1.6598 & 1.6599 & 0.8456 & 0.8456 & 0.8553 & 0.8580 \\
12 & 1.7446 & 1.7446 & 0.8241 & 0.8241 & 0.8702 & 0.8713 \\
\hline
\end{tabular}

Tabel 2, 3, 4 dan kurva dispersi pada Gambar 4 memperlihatkan bahwa pada daerah frekuensi ternormalisasi rendah untuk modus $\mathrm{TE}_{00}$, dengan $\mathrm{V} \leq 2,84$, nilai $\mathrm{B}, \mathrm{NW}_{\mathrm{x}}$ dan $\mathrm{NW}_{\mathrm{y}}$, fungsi pendekatan Hermite-Gaussian mengalami divergensi (susah konvergen) karena pada rentang harga ini konstanta propagasi bernilai imajiner yang seharusnya pada lapisan pemandu (lapisan film) bernilai real. Untuk pendekatan Hypergeometri, modus $\mathrm{TE}_{01}$ frekuensi ternormalisasi pada kisaran 4,86, modus $\mathrm{TE}_{11}$ cut-off masing-masing pada kisaran $\mathrm{V}=6,46$, sedangkan pendekatan Hermite-Gaussian cut-off pada $\mathrm{V}=4,73$ dan $\mathrm{V}=$ 6,67. Hasil ini memperlihatkan bahwa untuk kisaran $1,86 \leq \mathrm{V} \leq 2,72$ untuk modus $\mathrm{TE}_{00}$, pendekatan Hypergeometri sangat akurat dibandingkan dengan pendekatan HermiteGaussian, karena cenderung mendekati daerah cut-off yang memberikan lebar jendela optis yang cukup besar. Hal ini menunjukkan bahwa dua parameter pendekatan gaussian- 
eksponensial untuk modus dasar menggambarkan karakteristik propagasi dengan akurasi yang jauh lebih tinggi dibandingkan dengan parameter tunggal pendekatan gaussian.

Tabel 3. Nilai B, $\mathrm{Nh}_{\mathrm{x}}$ dan $\mathrm{Nh}_{\mathrm{y}}$ untuk modus TE01

\begin{tabular}{ccccccc}
\hline $\mathbf{V}$ & $\mathbf{N h x}$ & $\mathbf{N h y}$ & $\mathbf{N W x}$ & $\mathbf{N W y}$ & $\mathbf{B}_{\text {hyper }}$ & $\mathbf{B}_{\text {hermite }}$ \\
\hline 1 & - & - & - & - & - & - \\
2 & - & - & - & - & - & - \\
3 & - & - & - & - & - & - \\
4 & - & - & - & - & - & - \\
5 & 1.3406 & 1.0591 & 1.0253 & 1.0214 & 0.0588 & 0.0672 \\
6 & 1.4530 & 0.9938 & 0.9624 & 0.9100 & 0.2245 & 0.2646 \\
7 & 1.4946 & 0.9333 & 0.9099 & 0.9034 & 0.3641 & 0.4018 \\
8 & 1.5010 & 0.9158 & 0.9102 & 0.8481 & 0.4732 & 0.5024 \\
9 & 1.5390 & 0.9544 & 0.9099 & 0.8078 & 0.5557 & 0.5774 \\
10 & 1.6099 & 1.0308 & 0.9094 & 0.7768 & 0.6186 & 0.6348 \\
11 & 1.6734 & 1.1131 & 0.9088 & 0.7519 & 0.6677 & 0.6796 \\
12 & 1.7520 & 1.1943 & 0.9082 & 0.7313 & 0.7069 & 0.7155 \\
\hline
\end{tabular}

Pendekatan Hypergeometri untuk 2 parameter lebar dengan aspect ratio, a = 1 lebih akurat dibandingkan dengan satu parameter lebar untuk aspect ratio, a $=1$. Sekali lagi diperlihatkan bahwa, penambahan parameter lebar akan memperkecil galat relatif terhadap fungsi cobaan yang digunakan. Tetapi hasil yang ditunjukkan oleh pendekatan hypergeometri memperlihatkan bahwa penambahan parameter lebar untuk aspect ratio berbeda ( $\mathrm{a}=1$ dan $\mathrm{a}=2$ ) tidak terlau signifikan terhadap akurasi hasil perhitungan, artinya bahwa untuk pendekatan Hypergeometri dengan 1 ataupun 2 parameter untuk aspect ratio sama, akurasi hasil perhitungan adalah hampir sama. Jika analisa difokuskan pada daerah bermoda tunggal, yang berarti bahwa analisa dibatasi hanya untuk modus $\mathrm{TE}_{00}$, yaitu pada kisaran besarnya $\mathrm{V}$, hanya modus $\mathrm{TE}_{00}$ yang dirambatkan dengan jumlah energi cahaya mempunyai prosentase maksimum.

Tabel 4. Nilai B, $\mathrm{Nh}_{\mathrm{x}}$ dan $\mathrm{Nh}_{\mathrm{y}}$ untuk modus TE11

\begin{tabular}{ccccccc}
\hline $\mathrm{v}$ & $\mathbf{N h x}$ & Nhy & $\mathbf{N W x}$ & $\mathbf{N W y}$ & $\mathbf{B}_{\text {hyper }}$ & $\mathbf{B}_{\text {hermite }}$ \\
\hline 1 & - & - & - & - & - & - \\
2 & - & - & - & - & - & - \\
3 & - & - & - & - & - & - \\
4 & - & - & - & - & - & - \\
5 & - & - & - & - & - & - \\
6 & - & - & - & - & - & - \\
7 & 0.9972 & 0.9972 & 0.9099 & 0.9099 & 0.0537 & 0.0615 \\
8 & 0.9778 & 0.9714 & 0.9086 & 0.9086 & 0.2011 & 0.1884 \\
9 & 1.0029 & 0.9997 & 0.9069 & 0.9069 & 0.3229 & 0.2758 \\
10 & 1.0619 & 1.0561 & 0.9049 & 0.9049 & 0.4200 & 0.3388 \\
11 & 1.1275 & 1.1276 & 0.9025 & 0.9025 & 0.4966 & 0.3858 \\
12 & 1.2058 & 1.2175 & 0.8998 & 0.8998 & 0.5573 & 0.4221 \\
\hline
\end{tabular}




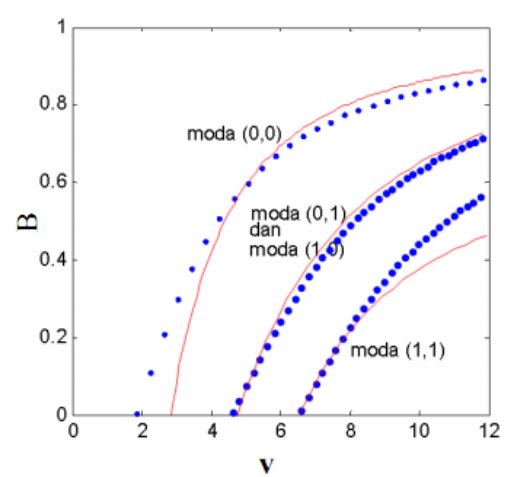

Gambar 4. Hubungan konstanta propagasi vs Frekuensi ternormalisasi empat moda pertama orde tinggi

\section{KESIMPULAN}

Berdasarkan hasil kajian dapat disimpulkan bahwa pendekatan yang digunakan untuk menyelesaikan pola medan pandu gelombang persegi dengan dua parameter lebar cukup akurat dan mampu mendeskripsikan daerah gelombang optik untuk frekuensi rendah. Hasil perhitungan komputasi secara numerik pada beberapa harga frekuensi ternormalisasi untuk pandu gelombang persegi diperoleh nilai konstanta propagasi yang sulit konvergen. Untuk itu, perlu diujicoba beberapa fungsi pendekatan lain.

\section{DAFTAR PUSTAKA}

1. Tamir T. Guided-wave optoelectronics. Second Edition. Springer-Verlag; 1990

2. Hunsperger RG. Integrated optics. Springer Science Business Media. DOI $10.1007 / \mathrm{b} 987302.2009$

3. Erteza IA. A variational analysis of rectangular channel dielectric waveguides using gaussian modal approximation. [Ph.D Disertation]. Stanford Univ;1993

4. Boim Y., et al. Application of the variational-moment method to symetric and nonsymetric waveguide. Applied Optic. 1994 August 20; 32 [24]

5. Kim H, Y, Choy Yoong T, Ghassan Yassin, Kee Choon Y. Attenuation in rectangular waveguides with finite conductivity walls. Radioengineering. 2011 June; 20(2).

6. Alexey Pokrovskiy, Natalia Meleshko. Electromagnetic field simulation in technical diagnostics. ECNDT-We.4.3.3. Moscow Russia: Moscow Power Energy Institute. Technical University; 2006.

7. Narkhedkar SK, Sinha SK. Variational metho d for ob jective analysis of $\mathrm{s}$ calar variable and its derivative. J. Earth S yst. Sci . 2008 October; 117(5): 621-635

8. Islam AE, Ahmed AK, Alexander BY, Allen WG. Full-wave modal analysis of a right/left-handed corrugated rectangular waveguide. Center of Applied Electromagnetic Systems Research. University of Mississippi. 2014.

9. Lokollo, Richar R. Analisis variasional dalam memodelkan relasi dispersi pemandu gelombang planar step indeks menggunakan medan listrik cobaan hypergeometri. Arika. 2014 Pebruari; 8(1). 